Article

\title{
Are Women More Likely to Seek Advice than Men? Evidence from the Boardroom
}

\author{
Maurice Levi ${ }^{1}$, Kai Li ${ }^{1, *, \dagger}$ and Feng Zhang ${ }^{2, \dagger}$
}

1 Sauder School of Business, University of British Columbia, 2053 Main Mall, Vancouver, BC V6T 1Z2, Canada; E-Mail: maurice.levi@sauder.ubc.ca

2 David Eccles School of Business, University of Utah, 1655 East Campus Center Drive, Salt Lake City, UT 84112, USA; E-Mail: feng.zhang@business.utah.edu

$\dagger$ These authors contributed equally to this work.

* Author to whom correspondence should be addressed; E-Mail: kai.li@sauder.ubc.ca; Tel.: +1-604-822-8353; Fax: +1-604-822-4695.

Academic Editor: Michael McAleer

Received: 15 December 2014 / Accepted: 4 February 2015 / Published: 16 February 2015

\begin{abstract}
It is commonly believed that women are more likely to seek advice than men; for example, on aspects of health or asking for directions when lost. This paper investigates whether women's relatively greater propensity for advice seeking extends to important business decisions, specifically those involving corporate takeovers. Consistent with the evidence from other contexts, we show that the presence of female directors on target boards is positively and significantly associated with target boards seeking advice from top-ranked financial advisors. In contrast, we do not observe any significant association between the presence of female directors on bidder boards and their engagement of topranked financial advisors. We argue that the presence of a gender effect for target boards but not for bidder boards is consistent with less overconfident female versus male directors on bidder boards initiating fewer bids, higher litigation risk facing target boards for accepting too little, and the different type of advice sought by bidders and target firms.
\end{abstract}

Keywords: seeking advice; financial advisors; director gender; overconfidence; takeovers

JEL Classification: G34 


\section{Introduction}

There is a commonly held belief that women are more likely than men to seek advice; examples of this behavior include seeking help from health professionals or via the Internet, and seeking directions when lost. This gender difference in advice seeking has been supported by research across a range of behavioral contexts [1-5]. The tendency for women to more readily seek advice than men is also supported by a 2010 study conducted by the British automobile insurance company, Sheila's Wheels (see http://abcnews.go.com/Travel/male-drivers-lost-longer-women-refuse-directions/story?id=11949176). As a result of men's reluctance to seek advice, the Sheila's Wheels study shows that men drive more miles each year while lost than women do, and when lost, 26 percent of men wait at least half an hour before asking for help (Op. cit) (Recent research suggests differences in directional advice seeking may reflect differences in brain activity; see http://www.iflscience.com/brain/why-some-people-reallydont-need-ask-directions).

This paper asks whether the greater propensity for women to seek advice extends to business decisions. Specifically, when considering whether to go ahead with a corporate acquisition, is the extent of female representation on a bidder or target board associated with the likelihood of that board seeking high-quality professional advice?

In order to investigate whether the presence of female directors plays a role in seeking outside advice from top-ranked financial advisors, we examine over 2500 merger and acquisition (M \& A) deals over the period 1997-2010. We show that there is no significant association between the fraction of female directors on a bidder board and the likelihood of that board consulting with a top-ranked M\&A advisor. On the other hand, using close to 500 M \& A deals over the same sample period 19972010 for which we have information on target boards, we show that there is a positive and significant association between the fraction of female directors on target boards and their likelihood of consulting with a top-ranked $M$ \& A advisor. In terms of the economic significance, each ten-percent of female directors on a target board increases the likelihood of it engaging a top ten-ranked (top 20-ranked) advisor by 7.6 (1.7) percent.

Our goals in this paper are to report the association between director gender and consultation with highly-ranked financial advisors for bidder and target firms, and to suggest possible reasons for asymmetric connections. Our investigation shares the same endogeneity limitations as the majority of investigations relating to corporate boards. For example, one could argue that a CEO who wants to seek advice chooses women board members who he believes more likely than men to argue in favor of seeking advice from $\mathrm{M} \& \mathrm{~A}$ advisors when considering acquisitions. Alternatively, maybe a CEO who wants to go ahead with only minimal consultation is not appealing to women board members who are likely to lobby for engaging a financial advisor. In these cases, causation does not go from female directors to business decisions, but from business decisions to female directors. Nevertheless, in either case the outcome can be traced back to female board members being more likely to seek advice, or at least being perceived to be more likely to seek advice. As such, we can still examine the association between female representation on corporate boards and boards' propensities to consult with highlyranked financial advisors. Furthermore, concern over endogeneity is to some extent mitigated by the robustness of the associations reported in this paper after controlling for observable firm and director characteristics and industry effects. 
Our paper contributes to the growing finance literature on whether and how personal or behavioral traits of corporate executives are related to corporate decisions. In terms of CEO characteristics and experiences, Malmendier and Tate [6,7] find that CEO overconfidence significantly affects corporate investment and $\mathrm{M} \& \mathrm{~A}$ decisions. Levi, Li, and Zhang [8] document a strong hormone effect in M \& As. Malmendier, Tate, and Yan [9] and Graham, Harvey, and Puri [10] find that measurable CEO characteristics, such as early-life experiences, optimism, and risk-aversion have significant explanatory power for corporate financing decisions. Relatedly, Cronqvist, Makhija, and Yonker [11] find that firms' behavior is consistent with how their CEOs behave personally in the context of leverage choices.

In terms of gender differences at the executive level, Adams and Ferreira [12] find that female directors are more effective monitors than male directors. Using responses to mandated changes in Norwegian boards, Ahern and Dittmar [13] find that the quota requiring greater female representation on corporate boards is negatively associated with firm performance. Masta and Miller [14] further show that the presence of more female directors on Norwegian corporate boards is associated with fewer employee layoffs, higher labor costs, and lower profits. Similarly, using plant-level data in the US, Tate and Yang [15] find that female CEOs help cultivate more female-friendly corporate environments, with smaller wage gaps between genders. Huang and Kisgen [16] compare corporate financial and investment decisions made by female executives with those by male executives and find that men exhibit relatively greater overconfidence in significant corporate decision making compared with women. Similarly, Faccio, Marchica, and Mura [17] find that firms run by female CEOs have lower leverage, less volatile earnings, and a higher chance of survival than firms run by male CEOs.

In an M \& A setting, Levi, Li, and Zhang [18] show that risk homeostasis, adjustment of behavior to maintain risk, affects corporate acquisition decisions. Levi, Li, and Zhang [19] show that less overconfident female directors less overestimate merger gains and as a result, firms with female directors are less likely to make acquisition bids and if they do, pay lower bid premia. We add to this literature by showing that women's relatively greater propensity for advice seeking than men extends to important corporation decisions involving takeovers. By considering possible gender effects in the context of large, discrete decisions, we can gauge whether it is worth investigating possible gender effects in day-to-day operations. Furthermore, our findings in this paper reinforce prior observations that female directors are more effective monitors [12], and that female directors are associated with fewer acquisition bids [19].

The outline of the paper is as follows. The next section reviews the related literature on choices of advisors and develops our hypotheses. Section 3 describes our empirical specification and data. Section 4 presents the results on the association between female directors and consultation with advisors for the bidders. Section 5 presents the results for the target firms. Section 6 implements additional investigation. We summarize and conclude in Section 7.

\section{Literature Review and Hypothesis Development}

\subsection{Related Literature}

Our research is related to a strand of the $M$ \& A literature that examines choices of financial advisors. Bowers and Miller [20] find that in acquisitions where either the bidder or target firm 
employs first-tier financial advisors, the total abnormal dollar return is greater than when neither firm employs a prestigious advisor: Advice seeking is a value-enhancing activity in which the expected benefit, broadly defined, presumably exceeds the cost for bidders or target firms or both. Servaes and Zenner [21] show that transaction costs, information asymmetry, and agency considerations help to explain investment banking choices in M \& As: Firms are more likely to hire consultants when the transaction is complex, when the bidder lacks prior experience, when the target firm operates in multiple lines of business, or when the bidder has low insider ownership. Rau [22] shows that advisor reputation is positively associated with the likelihood of deal completion and the advisor's market share, and negatively and significantly associated with the client's announcement-period return, but is not significantly associated with the bid premium. Kisgen, Qian, and Song [23] show that fairness opinions are more likely to be obtained in complex transactions with greater uncertainty, such as tender offers, all-stock deals, and large deals, as well as in firms with better corporate governance practices such as having more independent directors and smaller boards. Bao and Edmans [24] find that certain banks are systematically associated with superior M \& A returns, while there is a negative association between highly-ranked advisors and bidder announcement-period returns. Finally, Golubov, Petmezas, and Travlos [25] show that highly-ranked advisors are positively associated with bidder announcement-period returns only in acquisitions involving public target firms.

\subsection{Our Hypothesis}

In this paper, we take a fresh angle, examining whether director gender matters in board decisions to hire top-ranked and presumably high-quality advisors who offer their expert opinions and guidance on whether and how to pursue a merger or acquisition - typically a very important, complex corporate decision invariably involving many unique challenges.

The behavioral differences of gender in general are non-controversial. One gender difference of particular note is that women are less overconfident than men. Lower overconfidence may take the form of women believing the precision of their estimates to be less precise than men believe their own estimates to be (see, for example, [18], Barber and Odean [26]), which is consistent with the greater propensity for advice seeking by women than by men. Lower overconfidence may also take the form of women having a less favorable estimate than men of expected outcomes, particularly those involving large, discrete events with slow feedback such as M \& As (see [6,27]). Either form of lower overconfidence-but especially the former-is consistent with women being more likely to seek advice, since useful advice should narrow the dispersion of estimates of potential outcomes. That is, for a given target, women may have higher variance and lower expected value of the potential outcome.

Women are also more cautious, a matter that can be attributed to the greater investment that women make in the process of reproduction and thereby in the survival of our species [28]. This is evidenced by girls' safer play behaviors and women's generally more cautious behaviors involving sex, drugs and alcohol, gambling, driving, and employment choices [29]. In an M \& A setting, there are litigation risks facing bidder (target) boards for paying too much (accepting too little), prompting female directors to hire financial advisors. 
Whether the matter be that women exhibit lower overconfidence, greater caution or any other related characteristic, the possible gender-based behavioral differences in propensity to seek advice suggest the following null hypotheses and two-tail alternative hypotheses:

With respect to bidder boards hiring advisors:

$\boldsymbol{H}_{0}$ : The fraction of female directors on a bidder board is not associated with its propensity to hire top-ranked advisors when pursuing an acquisition target.

$\boldsymbol{H}_{1}$ : The fraction of female directors on a bidder board is associated with its propensity to hire top-ranked advisors when pursuing an acquisition target.

With respect to target boards hiring advisors:

$\boldsymbol{H}_{0}:$ The fraction of female directors on a target board is not associated with its propensity to hire top-ranked advisors when receiving an acquisition bid.

$\boldsymbol{H}_{1}$ : The fraction of female directors on a target board is associated with its propensity to hire top-ranked advisors when receiving an acquisition bid.

\section{Model Specification and Data}

\subsection{Model Specification}

To explore the role of board gender diversity in hiring quality $\mathrm{M} \& \mathrm{~A}$ advisors, we run the following cross-sectional Probit regression focusing on the fraction of female directors on a board:

$$
\begin{aligned}
\text { Advisor ranking }_{i} & =\alpha_{0}+\beta_{1} \% \text { Female director } s_{i}+\beta_{2} \text { Unfriendly deal }_{i} \\
& +\beta_{3} \text { Bidder not first bidder }_{i}+\beta_{4} \text { Bidder pays all in cash }_{i} \\
& \left.+\beta_{5} \text { Ln }_{\text {Transaction value }}\right)+\beta_{6} \text { Relative size }_{i}+\beta_{7} \text { Diversifying deal }_{i} \\
& +\beta_{8} \text { Director ownership }{ }_{i}+\beta_{9} \text { Board independency }_{i}+\beta_{10} \text { Board size }_{i} \\
& +\beta_{11} \text { CEObeing COB } \text { CE }_{i}+e_{i} .
\end{aligned}
$$

where the dependent variable takes a value of one if a top five (top ten, or top 20) financial advisor is hired, and zero otherwise. The controls for firm characteristics are motivated by [21-23]. We also control for year and industry fixed effects (based on the 48-industry classifications of Fama and French [30]). The control variable of particular interest is a measure of the board gender diversity of sample bidders or target firms - the fraction of female directors on a board.

\subsection{Bidder/Target Firm Samples}

To form our sample, we start with all M \& A deals initiated over the period 1997-2010 in Thomson Reuter's SDC database (The data on firm board characteristics from RiskMetrics are available since 1997. Therefore, our M \& A sample starts from that year.). The original sample has 152,123 deals. Following Rau [22], we require an M \& A deal to take the form of a merger (SDC deal form M) or acquisition of majority interest (AM). This filter significantly reduces the number of deals to 32,216. We then divide the sample into two: the bidder sample and the target firm sample. To be included in the bidder (target firm) sample, the bidder (target firm) must be a public firm with available financial information from Compustat. The initial bidder sample consists of 19,110 deals, and the initial target 
firm sample consists of 9094 deals. We then exclude deals without data on deal characteristics, e.g., relative size and transaction value. This requirement reduces the bidder sample to 7967 deals, and reduces the target firm sample to 3563 deals. The board and director information is retrieved from the RiskMetrics database, which is available only for S\&P 1500 firms, at the date of the most recent annual shareholder meeting prior to the bid announcement. Our final bidder sample consists of 2595 deals, and our final target firm sample consists of 483 deals.

\subsection{Ranking $M \&$ A Financial Advisors}

We rank financial advisors based on their market share. Our ranking methodology closely follows Rau [22]. The data on M\&A financial advisors are retrieved from Thomson Reuter's SDC database over the period 1990-2010 (The SDC's data on M \& A financial advisors start from 1980. Our sample period is from 1997-2010. We start ranking advisors from the year 1990 to leave a seven-year period before the beginning of our sample period. We exclude the data in the 1980s because the reputation of a financial advisor changes over time and thus the reputation in the 1980s is less relevant for our sample period.). The transaction value of an $\mathrm{M} \& \mathrm{~A}$ deal is accredited to the advisors that represent either the bidder or the target firm. We include mergers, acquisitions of majority interest, repurchases, buybacks, and exchange offers, both completed and withdrawn ones. Following [22], if a financial advisor is a subsidiary of another advisor, we accredit the deal to the specific advising entity instead of its ultimate parent to avoid misclassifications. For example, credit for transactions advised by Merrill Lynch before its takeover by Bank of America would be credited to Merrill Lynch.

For each advisor, we sum up the transaction values (adjusted to 2010 dollars using the CPI) of the M \& A deals it advised over the period when the advisor is active, and then compute its average annual deal value over that period. For example, if the first deal advised by an advisor is in 1993 and the last deal in 2007, the average annual deal value of this advisor is calculated as the sum of deal values it advised divided by 15 (=2007 - 1993 + 1). In each year from 1990-2010, all advisors active in that year are ranked based on their average annual deal value. The advisor with the greatest average annual deal value is ranked one, the advisor with the second greatest deal value is ranked two, and so on. Some advisors are active in only a single year and have advised very few deals. To avoid rendering a prestigious rank to them, the advisors that are active in only one year and have advised less than twenty deals in total are ranked after other more active advisors (Admittedly, the cut-off number of twenty is arbitrary. However, using alternative cut-offs does not qualitatively change our results.). Our ranking methodology yields reasonable rankings of the financial advisors. For example, our top ten advisors in 2010 are all among the top ten advisors in the Thomson Reuters 2010 league table (based on announced transaction value in 2010 only; see Appendix A for details of the top ten advisors identified by us.

\section{Bidder Board Gender Diversity and M \& A Financial Advisors}

\subsection{Bidder Sample Overview}

Table 1 presents the descriptive statistics of the bidder sample. Appendix B provides definitions of variables. 
The average number of advisors hired by the bidder is 0.68 , and the median is one. The fraction of bidders engaging financial advisors is about 60 percent (This number is computed when the information on the identity of the financial advisor is available - missing advisor data is treated as firms not hiring an advisor. As such, our results need to be interpreted with caution. We also checked and found that SDC's coverage on deals done "in house"-without hiring a financial advisor-was incomplete over our sample period.). In contrast, Kisgen, Qian, and Song [23] show that 37 percent of bidders in their sample obtain a third-party assessment of the fairness of a merger or acquisition. About a quarter of them hire from the top five advisors, over a third hire from the top ten advisors, and over 40 percent of them hire from the top 20 advisors. The mean (median) rank of bidder advisors is 20 (7). Using the relative position of investment banks placed in the tombstone announcements in the financial section of newspapers, Bowers and Miller [20] define first-tier investment banks (also referred to as prestigious banks) as those which are listed directly below the manager and co-manager. The rest are classified as second-tier banks. In their sample of acquirers, slightly less than half of them employ the first-tier investment banks. Rau [22] measures the market share of each investment bank as a fraction of the total value of transactions advised by the investment bank in each year over the period 1980-1993. He labels the top five advisors as "bulge bracket" or top-tier, the next 15 advisors as "major bracket" or second-tier, and the rest as third-tier. In his sample, about a third of the acquirers hire from the top-tier advisors, 27 percent hire from the second-tier advisors, and the rest hire from the third-tier advisors.

Table 1. Overview of the Bidder Sample.

\begin{tabular}{ccccccc}
\hline Variable & $\mathbf{N}$ & Mean & Std. Dev. & 5th Percentile & Median & 95th Percentile \\
\hline \# bidder advisors & 2595 & 0.679 & 0.769 & 0.000 & 1.000 & 2.000 \\
Bidder hires advisor & 2595 & 0.596 & 0.491 & 0.000 & 1.000 & 1.000 \\
Bidder hires a top 5 advisor & 2595 & 0.264 & 0.441 & 0.000 & 0.000 & 1.000 \\
Bidder hires a top 10 advisor & 2595 & 0.376 & 0.485 & 0.000 & 0.000 & 1.000 \\
Bidder hires a top 20 advisor & 2595 & 0.437 & 0.496 & 0.000 & 0.000 & 1.000 \\
Bidder advisor rank & 1546 & 20.141 & 40.000 & 1.000 & 7.000 & 79.000 \\
Bidder fraction of female directors & 2595 & 0.097 & 0.087 & 0.000 & 0.100 & 0.250 \\
Bidder fraction of independent female directors & 2595 & 0.086 & 0.083 & 0.000 & 0.091 & 0.231 \\
Bidder fraction of dependent female directors & 2595 & 0.011 & 0.033 & 0.000 & 0.000 & 0.100 \\
Unfriendly deal & 2595 & 0.030 & 0.171 & 0.000 & 0.000 & 0.000 \\
Bidder not first bidder & 2595 & 0.025 & 0.157 & 0.000 & 0.000 & 0.000 \\
Bidder pays all in cash & 2595 & 0.308 & 0.462 & 0.000 & 0.000 & 1.000 \\
Transaction value (\$B) & 2595 & 2.191 & 9.041 & 0.017 & 0.253 & 8.261 \\
Relative size & 2595 & 0.129 & 0.260 & 0.001 & 0.034 & 0.590
\end{tabular}

Our bidder sample consists of 2595 M \& As initiated during the period 1997-2010. The sample is retrieved from SDC and has available data for the bidder firm from RiskMetrics/Compustat/CRSP. See Appendix B for details of variable definitions. 
About three percent of takeover offers are perceived to be unfriendly, and in 2.5 percent of the cases the bidder is not the first bidder for the target. About a third of the offers involve payment all in cash. The average (median) size of the offer is $\$ 2.2$ billion ( $\$ 253$ million). The average (median) ratio of transaction value to bidder firm size (total assets) is 12.9 percent (3.4 percent). Over a third of the offers involve bidder and target firms in different industries, i.e., are diversifying deals. The average bidder board consists of 10.4 members, of which 9.7 percent are women and 67.6 percent are independent outsiders. These numbers are slightly higher than those reported in the study by Farrell and Hersch [31] who show that female directors comprise 8.6 percent of board members in a sample of Fortune 500 firms, and in the study by Paul [32] who shows that independent directors comprise 53 percent of board members in a sample of M \& A deals over the period 1982-1996. About 64 percent of the CEOs are also chairmen of the board (COB). The average board ownership is 7.4 percent.

\subsection{Bidder Board Gender Diversity and Reputation of Financial Advisors}

Table 2 presents the Probit/OLS regression results where the dependent variable is whether or not a bidder board engages a top-ranked advisor. Panel A employs the full bidder sample and examines the choice of hiring a top-ranked advisor vs. not hiring any advisor at all or not hiring a top-ranked advisor. Panel B employs a sample of bidders that have decided to hire an advisor, and examines their choice of hiring a top-ranked advisor.

We find that the fraction of female directors on the board is not significantly associated with the likelihood of the board hiring a top-ranked advisor. While this result could be taken at its face value, it may also be driven by a number of important differences between bidder and target firms.

First, there are differences in the way advisors are engaged by bidders versus target firms. Many deals are initiated (pitched) to bidders by investment banks. Financial advisors are hired to assist with internal discussions of the possibility of making an offer (considering an offer), and through this process may advise against proceeding with an offer (accepting an offer) [23]. Levi, Li, and Zhang [19] find that less overconfident female directors on the bidder board less overestimate merger gains and as a result, these firms with female directors are less likely to make acquisition bids. Target firms, on the other hand, are seeking advice in response to the bidder's approach. There is no such (symmetric) effect of female directors on the target board on deal initiations. It follows that these cases are not recorded as announced bids in the SDC M \& A database. Cases where advice has been sought for bidder board deliberations as to whether to proceed with an offer are, according to the findings of [19], likely to be disproportionately those where female directors have played a role as compared to cases where advice has been sought for target board deliberations as to whether to accept an offer. In short, the data on acquisition bids that are actually made and therefore end up in the SDC database may understate the influence of bidder female directors who are more likely to screen out potential bids that, as a consequence, never make it into the database: Women affect what we do not see.

Second, selling a firm is a much more litigious business than buying a firm (see the seminal legal case of Smith vs. Van Gorkom and the Delaware Supreme Court ruling that leads to the popularity of firms seeking fairness opinion). Lawsuits against the target board (brought by disgruntled shareholders who believe the offer price was insufficient) accompany almost every large takeover. Not surprisingly, Kisgen, Qian, and Song [23] find that $80 \%$ of target firms and only 37\% of bidders obtain a third-party 
assessment of the fairness of an offer. Given that female directors are more risk-averse than male directors, the former would be more likely to seek advice from top-ranked investment banks as a matter of protection. Being on the buy-side is not subject to the same litigation risk (We thank an anonymous referee for suggesting this argument.).

Table 2. Gender Diversity of the Bidder's Board and Financial Advisor Reputation.

Panel A: Probit regression results for all bidders; Panel B: Regression results for bidders that hire at least one financial advisor.

\begin{tabular}{|c|c|c|c|}
\hline Dependent Variable & Bidder Hires & Bidder Hires & Bidder Hires \\
\hline \multirow{6}{*}{ Estimation method } & a top 5 advisor & a top 10 Advisor & a top 20 advisor \\
\hline & $v s$ & $v s$ & $v s$. \\
\hline & a non-top 5 advisor & a non-top 10 & a non-top 20 \\
\hline & or no advisor & advisor or no advisor & advisor or no advisor \\
\hline & Probit & Probit & Probit \\
\hline & $(1)$ & $(2)$ & (3) \\
\hline \multirow{2}{*}{ Bidder fraction of female directors } & 0.0044 & 0.0944 & -0.0913 \\
\hline & $(0.106)$ & $(0.140)$ & $(0.155)$ \\
\hline \multirow{2}{*}{ Unfriendly deal } & -0.0107 & $-0.0948 *$ & -0.0948 \\
\hline & $(0.046)$ & $(0.057)$ & $(0.066)$ \\
\hline \multirow{2}{*}{ Bidder not first bidder } & 0.0011 & 0.0521 & 0.0964 \\
\hline & $(0.055)$ & $(0.082)$ & $(0.079)$ \\
\hline \multirow{2}{*}{ Bidder pays all in cash } & -0.0023 & -0.0008 & 0.0236 \\
\hline & $(0.019)$ & $(0.026)$ & $(0.028)$ \\
\hline \multirow{2}{*}{ Log Transaction value } & $0.1281 * * *$ & $0.1984 * * *$ & $0.2382 * * *$ \\
\hline & $(0.006)$ & $(0.009)$ & $(0.011)$ \\
\hline \multirow{2}{*}{ Relative size } & -0.0402 & 0.0476 & $0.2481 * *$ \\
\hline & $(0.036)$ & $(0.063)$ & $(0.101)$ \\
\hline \multirow{2}{*}{ Diversifying deal } & 0.0001 & -0.0052 & 0.0036 \\
\hline & $(0.020)$ & $(0.026)$ & $(0.029)$ \\
\hline \multirow{2}{*}{ Bidder director ownership } & $-0.1696 *$ & $-0.2077 *$ & $-0.2495 * *$ \\
\hline & $(0.087)$ & $(0.113)$ & $(0.121)$ \\
\hline \multirow{2}{*}{ Bidder board independence } & $0.1312 * *$ & $0.2130 * * *$ & $0.2066 * *$ \\
\hline & $(0.058)$ & $(0.077)$ & $(0.084)$ \\
\hline \multirow{2}{*}{ Bidder board size } & -0.0007 & 0.0005 & 0.0012 \\
\hline & $(0.003)$ & $(0.004)$ & $(0.004)$ \\
\hline \multirow{2}{*}{ Bidder CEO being COB } & -0.0197 & $-0.0444 *$ & $-0.0550 * *$ \\
\hline & $(0.018)$ & $(0.024)$ & $(0.026)$ \\
\hline Year fixed effects & Yes & Yes & Yes \\
\hline Industry fixed effects & Yes & Yes & Yes \\
\hline Observations & 2595 & 2595 & 2595 \\
\hline Pseudo R-squared & 0.28 & 0.34 & 0.39 \\
\hline
\end{tabular}


Table 2. Cont.

\begin{tabular}{|c|c|c|c|c|}
\hline Dependent Variable & Bidder Hires & Bidder Hires & Bidder Hires & Log (1/Bidder) \\
\hline Estimation method & $\begin{array}{c}\text { a top } 5 \text { advisor } \\
v s . \\
\text { a non-top } 5 \\
\text { advisor } \\
\text { Probit }\end{array}$ & $\begin{array}{c}\text { a top } 10 \text { advisor } \\
\text { vs. } \\
\text { a non-top } 10 \\
\text { advisor } \\
\text { Probit } \\
\end{array}$ & $\begin{array}{c}\text { a top } 20 \text { advisor } \\
\text { vs. } \\
\text { a non-top } 20 \\
\text { advisor } \\
\text { Probit } \\
\end{array}$ & (advisor rank) \\
\hline & $(1)$ & $(2)$ & (3) & $(4)$ \\
\hline $\begin{array}{l}\text { Bidder fraction of } \\
\text { female directors }\end{array}$ & $\begin{array}{l}0.0945 \\
(0.177)\end{array}$ & $\begin{array}{l}0.2091 \\
(0.161)\end{array}$ & $\begin{array}{c}-0.0060 \\
(0.115)\end{array}$ & $\begin{array}{l}0.4728 \\
(0.388)\end{array}$ \\
\hline Unfriendly deal & $\begin{array}{l}0.0073 \\
(0.080)\end{array}$ & $\begin{array}{c}-0.0856 \\
(0.086)\end{array}$ & $\begin{array}{c}-0.0044 \\
(0.065)\end{array}$ & $\begin{array}{c}-0.1948 \\
(0.160)\end{array}$ \\
\hline Bidder not first bidder & $\begin{array}{l}0.0050 \\
(0.084)\end{array}$ & $\begin{array}{l}0.0561 \\
(0.073) \\
\end{array}$ & $\begin{array}{l}0.0457 \\
(0.050)\end{array}$ & $\begin{array}{l}0.0667 \\
(0.174) \\
\end{array}$ \\
\hline Bidder pays all in cash & $\begin{array}{c}-0.0159 \\
(0.033) \\
\end{array}$ & $\begin{array}{c}-0.0162 \\
(0.032) \\
\end{array}$ & $\begin{array}{l}0.0103 \\
(0.022) \\
\end{array}$ & $\begin{array}{c}-0.0421 \\
(0.079) \\
\end{array}$ \\
\hline Log Transaction value & $\begin{array}{c}0.1300 * * * \\
(0.011) \\
\end{array}$ & $\begin{array}{c}0.1283 * * * \\
(0.011) \\
\end{array}$ & $\begin{array}{c}0.1021 * * * \\
(0.009)\end{array}$ & $\begin{array}{c}0.3748 * * * \\
(0.023)\end{array}$ \\
\hline Relative size & $\begin{array}{c}-0.1049 * * \\
(0.053)\end{array}$ & $\begin{array}{c}-0.0525 \\
(0.052)\end{array}$ & $\begin{array}{c}-0.0203 \\
(0.038)\end{array}$ & $\begin{array}{c}-0.3288 * * * \\
(0.112)\end{array}$ \\
\hline Diversifying deal & $\begin{array}{l}0.0051 \\
(0.033)\end{array}$ & $\begin{array}{l}-0.0014 \\
(0.030)\end{array}$ & $\begin{array}{l}0.0118 \\
(0.022)\end{array}$ & $\begin{array}{c}-0.0325 \\
(0.074)\end{array}$ \\
\hline Bidder director ownership & $\begin{array}{c}-0.2059 \\
(0.139) \\
\end{array}$ & $\begin{array}{c}-0.0965 \\
(0.120) \\
\end{array}$ & $\begin{array}{c}-0.1190 \\
(0.091) \\
\end{array}$ & $\begin{array}{c}-0.4674 \\
(0.300) \\
\end{array}$ \\
\hline $\begin{array}{l}\text { Bidder board } \\
\text { independence }\end{array}$ & $\begin{array}{c}0.1673 * \\
(0.097)\end{array}$ & $\begin{array}{c}0.1793 * * \\
(0.088)\end{array}$ & $\begin{array}{l}0.0607 \\
(0.065) \\
\end{array}$ & $\begin{array}{l}0.3148 \\
(0.211) \\
\end{array}$ \\
\hline Bidder board size & $\begin{array}{l}0.0005 \\
(0.005)\end{array}$ & $\begin{array}{l}0.0022 \\
(0.005)\end{array}$ & $\begin{array}{l}0.0010 \\
(0.003)\end{array}$ & $\begin{array}{l}0.0051 \\
(0.011)\end{array}$ \\
\hline Bidder CEO being COB & $\begin{array}{c}-0.0128 \\
(0.030)\end{array}$ & $\begin{array}{c}-0.0200 \\
(0.027)\end{array}$ & $\begin{array}{c}-0.0181 \\
(0.020)\end{array}$ & $\begin{array}{c}-0.0258 \\
(0.069)\end{array}$ \\
\hline Constant & & & & $\begin{array}{c}-4.9090 * * * \\
(0.236)\end{array}$ \\
\hline Year fixed effects & Yes & Yes & Yes & Yes \\
\hline Industry fixed effects & Yes & Yes & Yes & Yes \\
\hline Observations & 1546 & 1546 & 1546 & 1546 \\
\hline Adjusted/Pseudo R-squared & 0.17 & 0.22 & 0.30 & 0.25 \\
\hline
\end{tabular}

(B)

Our bidder sample consists of 2595 M \& As initiated during the period 1997-2010. The sample is retrieved from SDC and has available data for the bidder firm from RiskMetrics/Compustat/CRSP. Panel A presents regression results for all bidder firms, while Panel B only includes bidders that hire at least one financial advisor. We run Probit regressions and present the marginal effects in Panel A and the first three columns of Panel B. Column (4) of Panel B presents the OLS regression results. All model specifications employ robust standard errors (reported in parentheses below each coefficient). See Appendix B for details of variable definitions. Superscripts $* * *, * *$, and $*$ correspond to statistical significance at the one, five, and ten percent levels, respectively. 
Finally, the type of advice sought differs across bidders and target firms. Bidders seek help to identify operational synergies, which calls for in-depth industry expertise that is often lacking among financial advisors. Target firms are more concerned about "selling high" and seek help to value the terms of an offer, which is the expertise of typical financial advisors.

In addition to the above main findings, we show that large transactions and bidder boards with greater independent director representation are positively and significantly associated with the likelihood of the bidder board hiring top-ranked advisors, while high board director ownership is negatively and significantly associated with the likelihood of the bidder board hiring top-ranked advisors. These results are consistent with prior findings in [21,23].

Table 3. Overview of the Target Sample.

\begin{tabular}{ccccccc}
\hline Variable & $\mathbf{N}$ & Mean & Std. Dev. & 5th Percentile & Median & 95th Percentile \\
\hline \# target advisors & 483 & 1.379 & 0.672 & 1.000 & 1.000 & 3.000 \\
Target hires advisor & 483 & 0.981 & 0.135 & 1.000 & 1.000 & 1.000 \\
Target hires a top 5 advisor & 483 & 0.576 & 0.495 & 0.000 & 1.000 & 1.000 \\
Target hires a top 10 advisor & 483 & 0.720 & 0.449 & 0.000 & 1.000 & 1.000 \\
Target hires a top 20 advisor & 483 & 0.834 & 0.372 & 0.000 & 1.000 & 1.000 \\
Target advisor rank & 474 & 13.308 & 28.140 & 1.000 & 4.000 & 55.000 \\
Target fraction of female directors & 483 & 0.084 & 0.086 & 0.000 & 0.083 & 0.222 \\
Target fraction of independent female directors & 483 & 0.073 & 0.080 & 0.000 & 0.077 & 0.222 \\
Target fraction of dependent female directors & 483 & 0.011 & 0.034 & 0.000 & 0.000 & 0.100 \\
Unfriendly deal & 483 & 0.104 & 0.305 & 0.000 & 0.000 & 1.000 \\
Bidder not first bidder & 483 & 0.056 & 0.230 & 0.000 & 0.000 & 1.000 \\
Bidder pays all in cash & 483 & 0.222 & 0.416 & 0.000 & 0.000 & 1.000 \\
Transaction value (\$B) & 483 & 8.420 & 18.830 & 0.348 & 2.223 & 39.418 \\
Relative size & 483 & 0.369 & 0.445 & 0.007 & 0.227 & 1.236 \\
Diversifying deal & 483 & 0.317 & 0.466 & 0.000 & 0.000 & 1.000 \\
Target director ownership & 483 & 0.075 & 0.131 & 0.003 & 0.032 & 0.276 \\
Target board independence & 483 & 0.684 & 0.168 & 0.375 & 0.700 & 0.900 \\
Target board size & 483 & 9.503 & 3.064 & 5.000 & 9.000 & 15.000 \\
Target CEO being COB & 483 & 0.644 & 0.479 & 0.000 & 1.000 & 1.000 \\
\hline
\end{tabular}

Our target sample consists of 483 M \& As initiated during the period 1997-2010. The sample is retrieved from SDC and has available data for the target firm from RiskMetrics/Compustat/CRSP. See Appendix B for details of variable definitions.

\section{Target Board Gender Diversity and M \& A Financial Advisors}

\subsection{Target Firm Sample Overview}

Table 3 presents the descriptive statistics of the target firm sample. The average number of advisors hired by a target firm is 1.38 , and the median is one. The fraction of target firms hiring an advisor is close to 100 percent. In contrast, Kisgen, Qian, and Song [23] show that 80 percent of target firms in their sample obtain a third-party assessment of the fairness of a merger or acquisition. More than half of them hire from the top five advisors, close to three-quarters hire from the top ten advisors, and over 80 percent of them hire from the top 20 advisors. The mean (median) rank of target advisors is 13 (4). Bowers and Miller [20] show that in their sample of target firms slightly over 60 percent of them 
employ first-tier investment banks. Note that they define first-tier banks based on their relative positions in the tombstone announcements.

About a fifth of the takeover offers are perceived to be unfriendly, and in about six percent of the cases there have been prior bids for the target. About a fifth of the offers involve payment all in cash. The average (median) size of the offer is $\$ 8.4$ billion ( $\$ 2.2$ billion). The average (median) ratio of transaction value to bidder value (total assets) is 36.9 percent (22.7 percent). About a third of the offers involve bidders and target firms in different industries. The average target board consists of 9.5 members, of which 8.4 percent are women and 68.4 percent are independent outsiders. These numbers are similar to the numbers reported for the average bidder board (see our Table 1). About 64 percent of the CEOs are also chairmen of the board. The average board ownership is 7.5 percent.

\subsection{Target Board Gender Diversity and Reputation of Financial Advisors}

Table 4 presents the Probit/OLS regression results where the dependent variable is whether or not a target board hires a top-ranked advisor and the inverse of an advisor's ranking. Panel A employs the full target firm sample and examines the choice of hiring a top-ranked advisor vs. not hiring any advisor at all or not hiring a top-ranked advisor. Panel B employs a sample of target firms that have decided to hire an advisor and examine their choice of hiring a top-ranked advisor or not.

We find that the fraction of female directors on the target board is positively and significantly associated with the likelihood of the target board hiring a top-ten or top-20 ranked advisor. In terms of the economic significance, each ten-percent representation of female directors on the target board increases the likelihood of the board hiring from the top-ten (top-20) ranked advisors by 7.6 (1.7) percent $(=0.10 \times 0.549 / 0.720(=0.10 \times 0.138 / 0.834))$, where the second term in the numerator is the coefficient on the target firm proportion of female directors, and the denominator is the sample frequency of target boards hiring from the top-ten (top-20) ranked financial advisors, as shown in Table 3. This finding is consistent with the tendency for women vs. men to seek advice observed in other contexts such as seeking directions when lost and learning about health.

In addition to the above main findings, we show that unfriendly deals and large transactions are positively and significantly associated with the likelihood of the target boards engaging advisors. These findings are consistent with prior findings in Kisgen, Qian, and Song [23].

\section{Additional Investigation}

Prior work including Byrd and Hickman [33], Shivdasani [34], Cotter, Shivdasani and Zenner [35], Hermalin and Weisbach [36], and Paul [37] has shown that boards dominated by independent directors are more likely to make decisions that are in the interest of shareholders. If independence of directors matters, we expect the choice of financial advisors and their reputation to differ depending on whether a female director is an independent or a dependent director. Thus, we break down the fraction of female directors into the fraction of independent female directors and the fraction of dependent female directors.

Female directors on the bidder boards come primarily from outside (i.e., roughly 90 percent of female directors are independent, see Table 1), consistent with findings of Farrell and Hersch [31]. On average, the fraction of independent female directors on the bidder board is 8.6 percent, compared to the fraction of all female directors, which is 9.7 percent of the bidder board; hence the average fraction 
of dependent female directors on the bidder board is only about one percent. The distribution of independent and dependent female directors on the target boards is similar (i.e., again roughly 90 percent of female directors are independent, see Table 3).

In Table 5 Panels $A$ and $B$, we replace the fraction of female directors in Equation (1) with the fractions of independent and dependent female directors (relative to board size) to check the robustness of our findings on gender diversity and boards engaging a financial advisor. We show that independent female directors on the bidder board are not significantly associated with bidder advisor reputation, while dependent female directors are positively and significantly associated with the rank of the bidder advisors.

Table 4. Gender Diversity of the Target's Board and Financial Advisor Reputation. Panel A:

Probit regression results for all target firms; Panel B: Regression results for target firms that hire at least one financial advisor.

\begin{tabular}{|c|c|c|c|}
\hline Dependent Variable & Target Hires & Target Hires & Target Hires \\
\hline Estimation method & $\begin{array}{c}\text { a top } 5 \text { advisor } \\
\text { vs. } \\
\text { a non-top } 5 \text { advisor } \\
\text { or no advisor } \\
\text { Probit }\end{array}$ & $\begin{array}{c}\text { a top } 10 \text { advisor } \\
\text { vs. } \\
\text { a non-top } 10 \text { advisor } \\
\text { or no advisor } \\
\text { Probit }\end{array}$ & $\begin{array}{c}\text { a top } 20 \text { advisor } \\
\text { vs. } \\
\text { a non-top } 20 \text { advisor } \\
\text { or no advisor } \\
\text { Probit }\end{array}$ \\
\hline & $(1)$ & $(2)$ & $(3)$ \\
\hline Target fraction of female directors & $\begin{array}{r}0.4533 \\
(0.360) \\
\end{array}$ & $\begin{array}{c}0.5385 * * \\
(0.255) \\
\end{array}$ & $\begin{array}{c}0.1391 * \\
(0.084) \\
\end{array}$ \\
\hline Unfriendly deal & $\begin{array}{l}0.0418 \\
(0.085)\end{array}$ & $\begin{array}{c}0.1554 * * * \\
(0.032)\end{array}$ & $\begin{array}{c}0.0334 * * * \\
(0.010)\end{array}$ \\
\hline Bidder not first bidder & $\begin{array}{c}-0.0554 \\
(0.120) \\
\end{array}$ & $\begin{array}{c}-0.0707 \\
(0.108) \\
\end{array}$ & $\begin{array}{r}0.0100 \\
(0.021) \\
\end{array}$ \\
\hline Bidder pays all in cash & $\begin{array}{l}0.0703 \\
(0.071) \\
\end{array}$ & $\begin{array}{l}0.0404 \\
(0.046) \\
\end{array}$ & $\begin{array}{c}0.0209 * \\
(0.011) \\
\end{array}$ \\
\hline Log Transaction value & $\begin{array}{c}0.1471 * * * \\
(0.024) \\
\end{array}$ & $\begin{array}{c}0.1008 * * * \\
(0.019) \\
\end{array}$ & $\begin{array}{c}0.0256 * * * \\
(0.006) \\
\end{array}$ \\
\hline Relative size & $\begin{array}{c}-0.0087 \\
(0.060) \\
\end{array}$ & $\begin{array}{l}0.0377 \\
(0.048) \\
\end{array}$ & $\begin{array}{l}0.0119 \\
(0.015) \\
\end{array}$ \\
\hline Diversifying deal & $\begin{array}{c}-0.0583 \\
(0.065)\end{array}$ & $\begin{array}{c}-0.0309 \\
(0.045)\end{array}$ & $\begin{array}{c}-0.0177 \\
(0.016)\end{array}$ \\
\hline Target director ownership & $\begin{array}{c}-0.0110 \\
(0.199)\end{array}$ & $\begin{array}{c}-0.0903 \\
(0.136)\end{array}$ & $\begin{array}{l}0.0269 \\
(0.037)\end{array}$ \\
\hline Target board independence & $\begin{array}{c}-0.1063 \\
(0.171)\end{array}$ & $\begin{array}{c}-0.0345 \\
(0.127)\end{array}$ & $\begin{array}{c}-0.0525 \\
(0.046)\end{array}$ \\
\hline Target board size & $\begin{array}{l}0.0132 \\
(0.010)\end{array}$ & $\begin{array}{c}-0.0015 \\
(0.008)\end{array}$ & $\begin{array}{l}0.0014 \\
(0.002)\end{array}$ \\
\hline Target CEO being COB & $\begin{array}{c}0.1245 * * \\
(0.055) \\
\end{array}$ & $\begin{array}{l}0.0385 \\
(0.040) \\
\end{array}$ & $\begin{array}{l}0.0160 \\
(0.014) \\
\end{array}$ \\
\hline Year fixed effects & Yes & Yes & Yes \\
\hline Industry fixed effects & Yes & Yes & Yes \\
\hline Observations & 483 & 483 & 483 \\
\hline Pseudo R-squared & 0.22 & 0.27 & 0.29 \\
\hline
\end{tabular}


Table 4. Cont.

\begin{tabular}{|c|c|c|c|c|}
\hline Dependent Variable & Target Hires & Target Hires & Target Hires & Log (1/Target) \\
\hline Estimation method & $\begin{array}{c}\text { a top } 5 \text { advisor } \\
v s . \\
\text { a non-top } 5 \\
\text { advisor } \\
\text { Probit }\end{array}$ & $\begin{array}{c}\text { a top } 10 \text { advisor } \\
v s . \\
\text { a non-top } 10 \\
\text { advisor } \\
\text { Probit } \\
\end{array}$ & $\begin{array}{c}\text { a top } 20 \text { advisor } \\
v s . \\
\text { a non-top } 20 \\
\text { advisor } \\
\text { Probit } \\
\end{array}$ & (advisor rank) \\
\hline & $(1)$ & $(2)$ & (3) & (4) \\
\hline $\begin{array}{l}\text { Target fraction of } \\
\text { female directors }\end{array}$ & $\begin{array}{l}0.4170 \\
(0.358) \\
\end{array}$ & $\begin{array}{c}0.5253 * * \\
(0.247)\end{array}$ & $\begin{array}{c}0.1108 * \\
(0.066)\end{array}$ & $\begin{array}{c}1.5828 * * \\
(0.713)\end{array}$ \\
\hline Unfriendly deal & $\begin{array}{l}0.0325 \\
(0.085)\end{array}$ & $\begin{array}{c}0.1497 * * * \\
(0.032)\end{array}$ & $\begin{array}{c}0.0234 * * * \\
(0.009)\end{array}$ & $\begin{array}{c}0.4765 * * * \\
(0.167)\end{array}$ \\
\hline Bidder not first bidder & $\begin{array}{c}-0.0572 \\
(0.118)\end{array}$ & $\begin{array}{c}-0.0731 \\
(0.107)\end{array}$ & $\begin{array}{l}0.0056 \\
(0.015)\end{array}$ & $\begin{array}{c}-0.1715 \\
(0.221)\end{array}$ \\
\hline Bidder pays all in cash & $\begin{array}{l}0.0694 \\
(0.071) \\
\end{array}$ & $\begin{array}{l}0.0435 \\
(0.045) \\
\end{array}$ & $\begin{array}{c}0.0172 * \\
(0.009) \\
\end{array}$ & $\begin{array}{l}0.2660 \\
(0.174) \\
\end{array}$ \\
\hline Log Transaction value & $\begin{array}{c}0.1400 * * * \\
(0.024)\end{array}$ & $\begin{array}{c}0.0914^{* * * *} \\
(0.019) \\
\end{array}$ & $\begin{array}{c}0.0159 * * * \\
(0.006)\end{array}$ & $\begin{array}{c}0.3499 * * * \\
(0.056) \\
\end{array}$ \\
\hline Relative size & $\begin{array}{l}0.0073 \\
(0.062) \\
\end{array}$ & $\begin{array}{l}0.0633 \\
(0.050) \\
\end{array}$ & $\begin{array}{l}0.0168 \\
(0.012) \\
\end{array}$ & $\begin{array}{l}0.1064 \\
(0.124)\end{array}$ \\
\hline Diversifying deal & $\begin{array}{c}-0.0393 \\
(0.066) \\
\end{array}$ & $\begin{array}{c}-0.0038 \\
(0.044) \\
\end{array}$ & $\begin{array}{c}-0.0004 \\
(0.010) \\
\end{array}$ & $\begin{array}{c}-0.1045 \\
(0.145) \\
\end{array}$ \\
\hline Target director ownership & $\begin{array}{c}-0.0021 \\
(0.197) \\
\end{array}$ & $\begin{array}{c}-0.1044 \\
(0.133) \\
\end{array}$ & $\begin{array}{l}0.0192 \\
(0.037) \\
\end{array}$ & $\begin{array}{l}0.1771 \\
(0.481) \\
\end{array}$ \\
\hline Target board independence & $\begin{array}{c}-0.1001 \\
(0.173) \\
\end{array}$ & $\begin{array}{c}-0.0769 \\
(0.127) \\
\end{array}$ & $\begin{array}{c}-0.0540 \\
(0.036) \\
\end{array}$ & $\begin{array}{c}-0.3581 \\
(0.450) \\
\end{array}$ \\
\hline Target board size & $\begin{array}{l}0.0122 \\
(0.010) \\
\end{array}$ & $\begin{array}{l}-0.0033 \\
(0.007) \\
\end{array}$ & $\begin{array}{l}0.0003 \\
(0.002) \\
\end{array}$ & $\begin{array}{l}0.0081 \\
(0.024) \\
\end{array}$ \\
\hline Target CEO being COB & $\begin{array}{c}0.1209 * * \\
(0.055)\end{array}$ & $\begin{array}{l}0.0324 \\
(0.039) \\
\end{array}$ & $\begin{array}{l}0.0106 \\
(0.011) \\
\end{array}$ & $\begin{array}{c}0.2516 * * \\
(0.127) \\
\end{array}$ \\
\hline Constant & & & & $\begin{array}{c}-4.2991 * * * \\
(0.651)\end{array}$ \\
\hline Year fixed effects & Yes & Yes & Yes & Yes \\
\hline Industry fixed effects & Yes & Yes & Yes & Yes \\
\hline Observations & 474 & 474 & 474 & 474 \\
\hline Adjusted/Pseudo R-squared & 0.21 & 0.26 & 0.29 & 0.21 \\
\hline
\end{tabular}

(B)

Our target sample consists of $483 \mathrm{M} \mathrm{\&} \mathrm{As} \mathrm{initiated} \mathrm{during} \mathrm{the} \mathrm{period} \mathrm{1997-2010.} \mathrm{The} \mathrm{sample} \mathrm{is} \mathrm{retrieved}$ from SDC and has available data for the target firm from RiskMetrics/Compustat/CRSP. Panel A presents regression results for all target firms, while Panel B only includes target firms that hire at least one financial advisor. We run Probit regressions and present the marginal effects in Panel A and the first three columns of Panel B. Column (4) of Panel B presents the OLS regression results. See Appendix B for details of variable definitions. All model specifications employ robust standard errors (reported in parentheses below each coefficient). Superscripts $* * *, * *$, and * correspond to statistical significance at the one, five, and ten percent levels, respectively. 
Table 5. Board Gender Diversity and Financial Advisor Reputation: Independent vs. Dependent Female Directors. Panel A: Probit regression results for all bidders; Panel B: Regression results for bidders that hire at least one financial advisor; Panel C: Probit regression results for all target firms; Panel D: Regression results for target firms that hire at least one financial advisor.

\begin{tabular}{|c|c|c|c|}
\hline Dependent Variable & Bidder Hires & Bidder Hires & Bidder Hires \\
\hline \multirow{7}{*}{ Estimation method } & a top 5 advisor & a top 10 advisor & a top 20 advisor \\
\hline & $v s$ & $v s$ & $v s$ \\
\hline & a non-top 5 & a non-top 10 & a non-top 20 \\
\hline & advisor & advisor & advisor \\
\hline & or no advisor & or no advisor & or no advisor \\
\hline & Probit & Probit & Probit \\
\hline & $(1)$ & $(2)$ & $(3)$ \\
\hline \multirow{2}{*}{$\begin{array}{l}\text { Bidder fraction of independent } \\
\text { female directors } \\
\end{array}$} & -0.0618 & 0.0785 & -0.0488 \\
\hline & $(0.114)$ & $(0.148)$ & $(0.166)$ \\
\hline \multirow{2}{*}{$\begin{array}{l}\text { Bidder fraction of dependent } \\
\text { female directors }\end{array}$} & 0.3468 & 0.1738 & -0.3025 \\
\hline & $(0.260)$ & $(0.361)$ & $(0.404)$ \\
\hline \multirow{2}{*}{ Unfriendly deal } & -0.0123 & $-0.0951 *$ & -0.0945 \\
\hline & $(0.045)$ & $(0.057)$ & $(0.066)$ \\
\hline \multirow{2}{*}{ Bidder not first bidder } & -0.0009 & 0.0520 & 0.0967 \\
\hline & $(0.055)$ & $(0.082)$ & $(0.079)$ \\
\hline \multirow{2}{*}{ Bidder pays all in cash } & -0.0033 & -0.0010 & 0.0242 \\
\hline & $(0.019)$ & $(0.026)$ & $(0.028)$ \\
\hline \multirow{2}{*}{ Log Transaction value } & $0.1281 * * *$ & $0.1983 * * *$ & $0.2382 * * *$ \\
\hline & $(0.006)$ & $(0.009)$ & $(0.011)$ \\
\hline \multirow{2}{*}{ Relative size } & -0.0401 & 0.0477 & $0.2490 * *$ \\
\hline & $(0.036)$ & $(0.063)$ & $(0.101)$ \\
\hline \multirow{2}{*}{ Diversifying deal } & 0.0003 & -0.0052 & 0.0037 \\
\hline & $(0.020)$ & $(0.026)$ & $(0.029)$ \\
\hline \multirow{2}{*}{ Bidder director ownership } & $-0.1706 *$ & $-0.2081 *$ & $-0.2485 * *$ \\
\hline & $(0.087)$ & $(0.113)$ & $(0.121)$ \\
\hline \multirow{2}{*}{ Bidder board independence } & $0.1606 * * *$ & $0.2199 * * *$ & $0.1882 * *$ \\
\hline & $(0.062)$ & $(0.081)$ & $(0.089)$ \\
\hline \multirow{2}{*}{ Bidder board size } & -0.0005 & 0.0006 & 0.0011 \\
\hline & $(0.003)$ & $(0.004)$ & $(0.004)$ \\
\hline \multirow{2}{*}{ Bidder $\mathrm{CEO}$ being $\mathrm{COB}$} & -0.0198 & $-0.0445 *$ & $-0.0546 * *$ \\
\hline & $(0.018)$ & $(0.024)$ & $(0.026)$ \\
\hline Year fixed effects & Yes & Yes & Yes \\
\hline Industry fixed effects & Yes & Yes & Yes \\
\hline Observations & 2595 & 2595 & 2595 \\
\hline Pseudo R-squared & 0.29 & 0.34 & 0.38 \\
\hline
\end{tabular}


Table 5. Cont.

\begin{tabular}{|c|c|c|c|c|}
\hline Dependent Variable & Bidder Hires & Bidder Hires & Bidder Hires & Log (1/Bidder) \\
\hline Estimation method & $\begin{array}{c}\text { a top } 5 \text { advisor } \\
v s . \\
\text { a non-top } 5 \\
\text { advisor } \\
\text { Probit }\end{array}$ & $\begin{array}{c}\text { a top } 10 \text { advisor } \\
v s . \\
\text { a non-top } 10 \\
\text { advisor } \\
\text { Probit }\end{array}$ & $\begin{array}{c}\text { a top } 20 \text { advisor } \\
\text { vs. } \\
\text { a non-top } 20 \\
\text { advisor } \\
\text { Probit }\end{array}$ & (advisor rank) \\
\hline & $(1)$ & $(2)$ & $(3)$ & $(4)$ \\
\hline $\begin{array}{l}\text { Bidder fraction of independent } \\
\text { female directors }\end{array}$ & $\begin{array}{c}-0.0602 \\
(0.192)\end{array}$ & $\begin{array}{l}0.1390 \\
(0.174)\end{array}$ & $\begin{array}{c}-0.0172 \\
(0.128)\end{array}$ & $\begin{array}{l}0.2244 \\
(0.418)\end{array}$ \\
\hline $\begin{array}{l}\text { Bidder fraction of dependent } \\
\text { female directors }\end{array}$ & $\begin{array}{l}0.9113 * * \\
(0.442)\end{array}$ & $\begin{array}{l}0.5682 \\
(0.428)\end{array}$ & $\begin{array}{l}0.0504 \\
(0.321)\end{array}$ & $\begin{array}{c}1.7816 * \\
(1.002)\end{array}$ \\
\hline Unfriendly deal & $\begin{array}{l}0.0040 \\
(0.081)\end{array}$ & $\begin{array}{c}-0.0863 \\
(0.087)\end{array}$ & $\begin{array}{c}-0.0042 \\
(0.065)\end{array}$ & $\begin{array}{c}-0.1996 \\
(0.159)\end{array}$ \\
\hline Bidder not first bidder & $\begin{array}{c}-0.0012 \\
(0.083)\end{array}$ & $\begin{array}{l}0.0546 \\
(0.073)\end{array}$ & $\begin{array}{l}0.0456 \\
(0.050)\end{array}$ & $\begin{array}{l}0.0594 \\
(0.173)\end{array}$ \\
\hline Bidder pays all in cash & $\begin{array}{c}-0.0172 \\
(0.033)\end{array}$ & $\begin{array}{c}-0.0169 \\
(0.032) \\
\end{array}$ & $\begin{array}{l}0.0102 \\
(0.022) \\
\end{array}$ & $\begin{array}{c}-0.0435 \\
(0.079) \\
\end{array}$ \\
\hline Log Transaction value & $\begin{array}{l}0.1302 * * * \\
\quad(0.011)\end{array}$ & $\begin{array}{l}0.1280 * * * \\
\quad(0.011)\end{array}$ & $\begin{array}{l}0.1024 * * * \\
(0.009)\end{array}$ & $\begin{array}{c}0.3741 * * * \\
(0.023)\end{array}$ \\
\hline Relative size & $\begin{array}{c}-0.1052 * * \\
(0.053)\end{array}$ & $\begin{array}{c}-0.0526 \\
(0.052)\end{array}$ & $\begin{array}{l}-0.0205 \\
(0.038)\end{array}$ & $\begin{array}{c}-0.3307 * * * \\
(0.112)\end{array}$ \\
\hline Diversifying deal & $\begin{array}{l}0.0070 \\
(0.033) \\
\end{array}$ & $\begin{array}{r}-0.0008 \\
(0.030) \\
\end{array}$ & $\begin{array}{l}0.0119 \\
(0.022) \\
\end{array}$ & $\begin{array}{l}-0.0284 \\
(0.074) \\
\end{array}$ \\
\hline Bidder director ownership & $\begin{array}{c}-0.2078 \\
(0.140) \\
\end{array}$ & $\begin{array}{r}-0.0985 \\
(0.120) \\
\end{array}$ & $\begin{array}{c}-0.1196 \\
(0.091) \\
\end{array}$ & $\begin{array}{c}-0.4618 \\
(0.299) \\
\end{array}$ \\
\hline Bidder board independence & $\begin{array}{c}0.2308 * * \\
(0.103)\end{array}$ & $\begin{array}{c}0.2061 * * \\
(0.093)\end{array}$ & $\begin{array}{l}0.0652 \\
(0.068) \\
\end{array}$ & $\begin{array}{c}0.4174 * \\
(0.226)\end{array}$ \\
\hline Bidder board size & $\begin{array}{l}0.0009 \\
(0.005)\end{array}$ & $\begin{array}{l}0.0024 \\
(0.005)\end{array}$ & $\begin{array}{l}0.0010 \\
(0.003)\end{array}$ & $\begin{array}{l}0.0057 \\
(0.011)\end{array}$ \\
\hline Bidder CEO being COB & $\begin{array}{c}-0.0120 \\
(0.030) \\
\end{array}$ & $\begin{array}{c}-0.0200 \\
(0.027)\end{array}$ & $\begin{array}{c}-0.0183 \\
(0.020) \\
\end{array}$ & $\begin{array}{c}-0.0252 \\
(0.069) \\
\end{array}$ \\
\hline Constant & & & & $\begin{array}{c}-4.9336 * * * \\
(0.237)\end{array}$ \\
\hline Year fixed effects & Yes & Yes & Yes & Yes \\
\hline Industry fixed effects & Yes & Yes & Yes & Yes \\
\hline Observations & 1546 & 1546 & 1546 & 1546 \\
\hline Adjusted/Pseudo R-squared & 0.17 & 0.22 & 0.3 & 0.25 \\
\hline
\end{tabular}

(B) 
Table 5. Cont.

\begin{tabular}{|c|c|c|c|}
\hline Dependent Variable & Target Hires & Target Hires & Target Hires \\
\hline \multirow{7}{*}{ Estimation method } & a top 5 advisor & a top 10 advisor & a top 20 advisor \\
\hline & $v s$ & $v s$. & $v s$ \\
\hline & a non-top 5 & a non-top 10 & a non-top 20 \\
\hline & advisor & advisor & advisor \\
\hline & or no advisor & or no advisor & or no advisor \\
\hline & Probit & Probit & Probit \\
\hline & $(1)$ & $(2)$ & $(3)$ \\
\hline \multirow{2}{*}{ Target fraction of independent female directors } & 0.3799 & $0.6263 * *$ & 0.0917 \\
\hline & $(0.392)$ & $(0.277)$ & $(0.084)$ \\
\hline \multirow{2}{*}{ Target fraction of dependent female directors } & 0.8058 & 0.1156 & $0.5153 * *$ \\
\hline & $(0.823)$ & $(0.561)$ & $(0.251)$ \\
\hline \multirow{2}{*}{ Unfriendly deal } & 0.0385 & $0.1593 * * *$ & $0.0306 * * *$ \\
\hline & $(0.085)$ & $(0.032)$ & $(0.010)$ \\
\hline \multirow{2}{*}{ Bidder not first bidder } & -0.0482 & -0.0794 & 0.0123 \\
\hline & $(0.119)$ & $(0.111)$ & $(0.018)$ \\
\hline \multirow{2}{*}{ Bidder pays all in cash } & 0.0673 & 0.0441 & 0.0187 \\
\hline & $(0.072)$ & $(0.047)$ & $(0.012)$ \\
\hline \multirow{2}{*}{ Log Transaction value } & $0.1476 * * *$ & $0.1016 * * *$ & $0.0241 * * *$ \\
\hline & $(0.024)$ & $(0.019)$ & $(0.007)$ \\
\hline \multirow{2}{*}{ Relative size } & -0.0089 & 0.0391 & 0.0111 \\
\hline & $(0.061)$ & $(0.049)$ & $(0.014)$ \\
\hline \multirow{2}{*}{ Diversifying deal } & -0.0602 & -0.0290 & -0.0190 \\
\hline & $(0.066)$ & $(0.046)$ & $(0.016)$ \\
\hline \multirow{2}{*}{ Target director ownership } & -0.0291 & -0.0714 & 0.0140 \\
\hline & $(0.201)$ & $(0.139)$ & $(0.038)$ \\
\hline \multirow{2}{*}{ Target board independence } & -0.0788 & -0.0646 & -0.0387 \\
\hline & $(0.180)$ & $(0.132)$ & $(0.043)$ \\
\hline \multirow{2}{*}{ Target board size } & 0.0132 & -0.0014 & 0.0011 \\
\hline & $(0.010)$ & $(0.008)$ & $(0.002)$ \\
\hline \multirow{2}{*}{ Target CEO being COB } & $0.1233 * *$ & 0.0406 & 0.0143 \\
\hline & $(0.055)$ & $(0.040)$ & $(0.013)$ \\
\hline Year fixed effects & Yes & Yes & Yes \\
\hline Industry fixed effects & Yes & Yes & Yes \\
\hline Observations & 483 & 483 & 483 \\
\hline Pseudo R-squared & 0.23 & 0.27 & 0.30 \\
\hline
\end{tabular}

(C) 
Table 5. Cont.

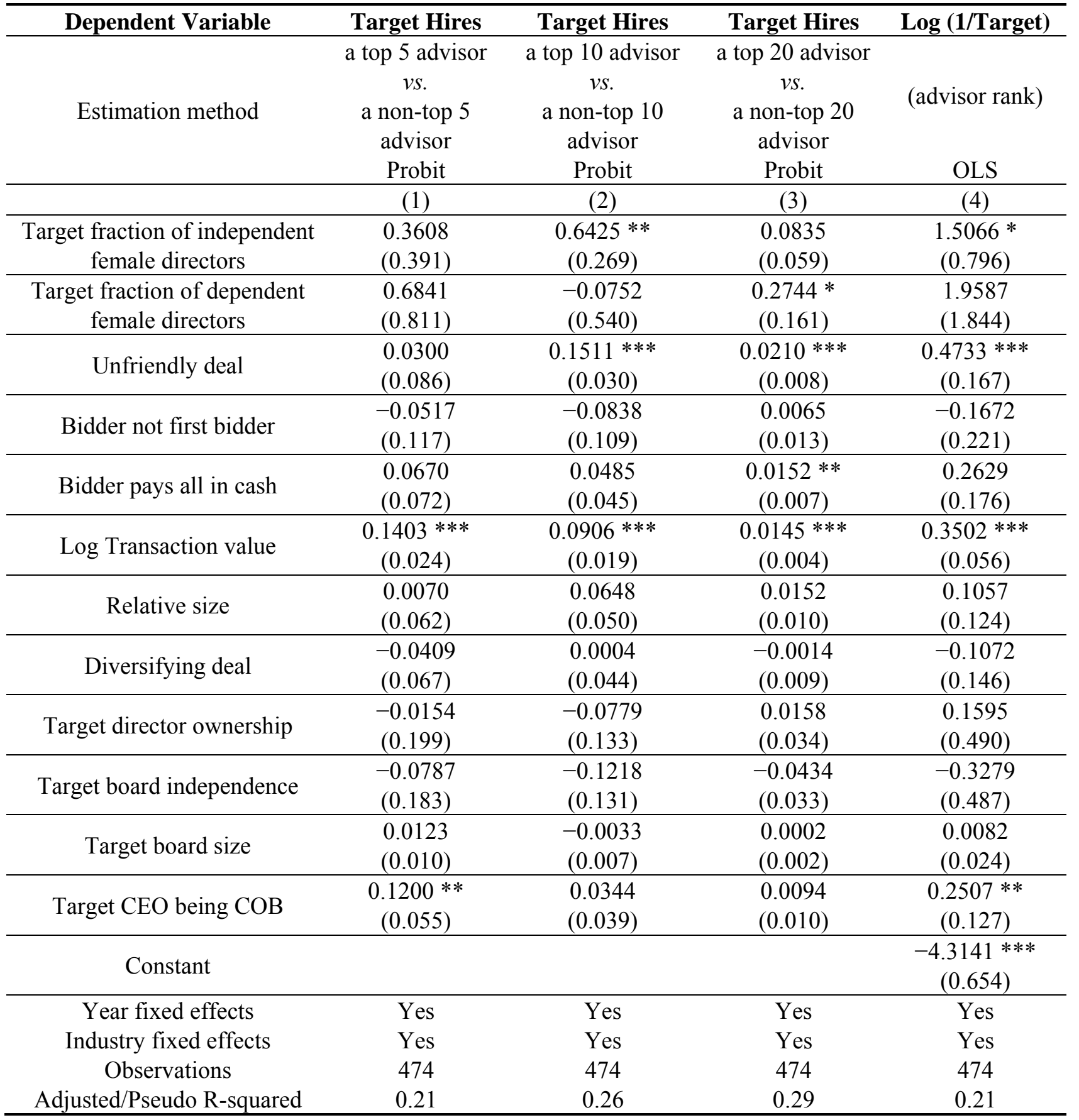

(D)

This table examines the role of independent and dependent female directors in hiring reputable financial advisors in M\&As. Our bidder and target samples are retrieved from SDC covering deals initiated over the period 1997-2010 and with available data for the bidder and target firm, respectively, from RiskMetrics/Compustat/CRSP. Panel A presents the regression results for all bidders, while Panel B only includes bidders that hire at least one financial advisor. Panel $\mathrm{C}$ presents the regression results for all target firms, while Panel D only includes target firms that hire at least one financial advisor. See Appendix B for details of variable definitions. We present marginal effects of each of the independent variable in Panels A and C and the first three columns of Panels B and D. Column (4) of Panels B and D present the OLS regression results. All model specifications employ robust standard errors (reported in parentheses below each coefficient). Superscripts ***, **, and * correspond to statistical significance at the one, five, and ten percent levels, respectively. 
In Table 5 Panels $\mathrm{C}$ and $\mathrm{D}$, we show that independent female directors on the target board are positively and significantly associated with the rank of the target advisors. Dependent female directors are positively and significantly associated with the rank of the target advisors. Based on these findings, we conclude that gender diversity on boards, not independence of boards, matter more in seeking high-quality financial advice.

In summary, our evidence suggests that both independent and dependent female directors are significantly associated with boards' engagement of high-quality consultants in M\&As.

In unreported analyses, we employ an indicator variable for the presence of female directors on bidder (target firm) boards and find that this binary variable for the presence of female directors on target boards is positively and significantly associated with the likelihood of these firms hiring top-ranked financial advisors, consistent with our main findings (We thank two anonymous referees for suggesting these analyses.). We also include both an indicator variable for a board to have only one female director and a second indicator variable for a board to have more than one female director and find that there is no significant association between the second indicator variable for the presence of multiple female directors on target boards and the likelihood of these firms hiring top-ranked financial advisors. We conclude that it is the presence of female directors on target boards with their higher propensities to seek advice, not the presence of multiple female directors, that drives our results.

To further explore the type of advice sought, we examine the relation between the presence of female directors and the likelihood of firms hiring multiple advisors [37] or seeking fairness opinion [23] and find no significant association between female directors and firms' likelihood of hiring multiple advisors or seeking fairness opinion. One possible explanation of our unsupportive findings is that, as Derrien and Dessaint [37] show, the rank of a bank influences its future deal flow. This creates incentives for banks to improve their ranks by selling fairness opinions and reducing fees when there are multiple advisors for the same deal and the same client. We also examine whether deal complexity, as measured by the size of the deal, all stock payment, and diversifying deals, changes the relation between the presence of female directors and the likelihood of firms hiring top-ranked financial advisors and find no significant interaction effects. In all cases, it is worth noting that our main findings on the significant association between the presence of female directors on target boards and target firms' hiring top-ranked advisors remain.

\section{Conclusions}

Consistent with evidence from other contexts that women are more likely than men to seek advice, this paper investigates the association between female board membership in bidder and target firms and the advice sought in corporate takeovers.

Our main finding is that the representation of female directors on target boards is positively and significantly associated with these boards employing highly-ranked M \& A financial advisors. Specifically, each ten-percent of female directors on a target board increases the likelihood of the board consulting with a top ten-ranked (top 20-ranked) advisor by 7.6 (1.7) percent. No such gender effect is observed for the bidder board. We argue that the presence of a gender effect for target boards but not for bidder boards may be due to less overconfident female versus male directors on bidder 
boards initiating fewer bids, higher litigation risk facing target boards for accepting too little, and the different type of advice sought by bidders and target firms.

Any finding that supports the importance of gender diversity on the prevalence of advice-seeking in M \& As is hardly surprising given the importance and complexity of these transactions. What we have demonstrated in this paper is that the effect of gender in the form of female board representation is consistent with other contexts, such as seeking help from health professionals or asking for directions when lost. We have also indicated that care must be taken due to the possibility of unobserved effects of gender occurring within the board, particularly the bidder board, which may be responding to investment banks' pitch to pursue deals. Women do make a difference in business. With more and more governments mandating gender balance on corporate boards, we can expect this mandate to have a sizeable effect on financial intermediaries such as the top-tier members of the investment banking industry.

\section{Acknowledgments}

We thank Mark Kamstra (the guest editor for the special issue), two anonymous referees, and Michael Meloche for helpful comments. Levi and Li acknowledge financial support from the Social Sciences and Humanities Research Council of Canada. We also acknowledge financial support from the Certified Management Accounting Society of British Columbia. All remaining errors are our own.

\section{Author Contributions}

All authors contributed to all aspects of this work.

\section{Appendix}

A. Financial Advisor Rankings in 2010.

\begin{tabular}{ccccccccc}
\hline Advisor name & \# Years & Beginning & End & \# Deals & Transaction & Average & Our Rank & Rank \\
\hline & advisor & of active & of active & over & value (\$B) & annual & by \\
& is & Period & period & active & over active & transaction & Thomson \\
& active & & & period & period & value (\$B) & Reuter \\
Goldman Sachs \& Co & 21 & 1990 & 2010 & 1700 & 5433.0 & 258.7 & 1 & 1 \\
Morgan Stanley \& Co & 21 & 1990 & 2010 & 1415 & 4190.8 & 199.6 & 2 & 2 \\
Citigroup & 8 & 2003 & 2010 & 378 & 1391.6 & 173.9 & 3 & 7 \\
Bank of America Merrill Lynch & 2 & 2009 & 2010 & 93 & 297.5 & 148.7 & 4 & 5 \\
JP Morgan \& Co Inc. & 18 & 1993 & 2010 & 849 & 2665.0 & 148.1 & 5 & 3 \\
Credit Suisse Group & 7 & 2004 & 2010 & 235 & 703.3 & 100.5 & 6 & 4 \\
UBS Investment Bank & 11 & 2000 & 2010 & 396 & 933.2 & 84.8 & 7 & 9 \\
Lazard & 11 & 2000 & 2010 & 275 & 781.6 & 71.1 & 8 & 10 \\
Barclays Capital & 4 & 2007 & 2010 & 90 & 238.3 & 59.6 & 9 & 6 \\
Deutsche Bank AG & 13 & 1998 & 2010 & 320 & 740.3 & 56.9 & 10 & 8 \\
\hline
\end{tabular}


B. Definition of Variables.

\begin{tabular}{|c|c|}
\hline Variable & Definition \\
\hline \# bidder (target) advisors & The number of financial advisors the bidder (target firm) employs, as reported in SDC. \\
\hline Bidder (target) hires advisor & $\begin{array}{l}\text { An indicator variable that takes the value of one if the bidder (target) employs at least one financial advisor, } \\
\text { and zero otherwise. }\end{array}$ \\
\hline $\begin{array}{l}\text { Bidder (target) hires a top } 5 \\
(10 \text { or } 20) \text { advisor }\end{array}$ & $\begin{array}{l}\text { An indicator variable that takes the value of one if at least one of the financial advisors employed by the bidder } \\
\text { (target firm) is ranked a top five (ten or twenty) advisor in the year the acquisition is announced, and zero otherwise. }\end{array}$ \\
\hline Bidder (target) advisor rank & $\begin{array}{l}\text { The rank of the financial advisor employed by the bidder (target firm). If the bidder (target firm) employs more than } \\
\text { one advisor, this is the rank of the most prestigious advisor. }\end{array}$ \\
\hline $\begin{array}{l}\text { Bidder (target) fraction of } \\
\text { female directors }\end{array}$ & The fraction of female directors on the bidder (target) board. \\
\hline $\begin{array}{l}\text { Bidder (target) fraction of } \\
\text { independent female directors }\end{array}$ & $\begin{array}{l}\text { The number of female directors who are not corporate executives - hence independent directors - divided by the } \\
\text { board size. }\end{array}$ \\
\hline $\begin{array}{l}\text { Bidder (target) fraction of } \\
\text { dependent female directors }\end{array}$ & $\begin{array}{l}\text { The number of female directors who are connected to the firm - hence dependent directors - divided by the } \\
\text { board size. }\end{array}$ \\
\hline Unfriendly deal & An indicator variable that takes the value of one if SDC does not regard this deal as "friendly". \\
\hline Bidder not first bidder & $\begin{array}{l}\text { An indicator variable that takes the value of one if the deal challenges an existing acquisition bid from another } \\
\text { bidder, and zero otherwise. }\end{array}$ \\
\hline Bidder pays all in cash & An indicator variable that takes the value of one if the bidder pays the target firm in cash only, and zero otherwise. \\
\hline Transaction value & Transaction value of the acquisition expressed in billions of dollars, adjusted to 2010 purchasing power using CPI. \\
\hline Relative size & $\begin{array}{l}\text { The transaction value divided by the market value of total assets of the bidder at the fiscal year end prior to the bid } \\
\text { announcement. }\end{array}$ \\
\hline Diversifying deal & $\begin{array}{l}\text { An indicator variable that takes the value of one if the bidder is not in the same Fama-French (1997) } 48 \text { industry as } \\
\text { the target firm, and zero otherwise. }\end{array}$ \\
\hline $\begin{array}{l}\text { Bidder (target) } \\
\text { director ownership }\end{array}$ & Ownership of all directors of the bidder (target firm). \\
\hline $\begin{array}{l}\text { Bidder (target) } \\
\text { board independence }\end{array}$ & $\begin{array}{l}\text { The fraction of independent bidder (target) directors. Bidder (target) board size is the number of directors on the } \\
\text { bidder (target) board. }\end{array}$ \\
\hline Bidder (target) board size & The number of directors on the bidder (target) board. \\
\hline $\begin{array}{l}\text { Bidder (target) } \mathrm{CEO} \\
\text { being } \mathrm{COB}\end{array}$ & $\begin{array}{l}\text { An indicator variable that takes the value of one if the bidder (target firm) CEO is also the chairman of the board } \\
\text { (COB), and zero otherwise. }\end{array}$ \\
\hline
\end{tabular}

\section{Conflicts of Interest}

The authors declare no conflicts of interest.

\section{References}

1. Addis, M.E.; Mahalik, J.R. Men, masculinity, and the contexts of help seeking. Am. Psychol. 2003, $58,5-14$.

2. Ybarra, M.; Sumam, M. Reasons, assessments and actions taken: Sex and age differences in uses of internet health information. Health Educ. Res. 2008, 23, 512-521.

3. O'Brien, R.; Hunt, K.; Hart, G. It's caveman stuff, but that is to a certain extent how guys still operate: Men's accounts of masculinity and help seeking. Soc. Sci. Med. 2005, 61, 503-516.

4. Croson, R.; Gneezy, U. Gender differences in preferences. J. Econ. Lit. 2009, 47, 448-474. 
5. Halder, S.; Ray, A.; Chakrabarty, P.K. Gender differences in information seeking behavior in three universities in West Bengal, India. Int. Inf. Libr. Rev. 2010, 42, 242-251.

6. Malmendier, U.; Tate, G. CEO overconfidence and corporate investment. J. Financ. 2005, 60, 2661-2700.

7. Malmendier, U.; Tate, G. Who makes acquisitions? CEO overconfidence and the market's reaction. J. Financ. Econ. 2008, 89, 20-43.

8. Levi, M.; Li, K.; Zhang, F. Deal or no deal: Hormones and the mergers and acquisitions game. Manag. Sci. 2010, 56, 1462-1483.

9. Malmendier, U.; Tate, G.; Yan, J. Overconfidence and early-life experiences: The effect of managerial traits on corporate financial policies. J. Financ. 2011, 66, 1687-1733.

10. Graham, J.R.; Harvey, C.R.; Puri, M. Managerial attitudes and corporate actions. J. Financ. Econ. 2013, 109, 103-121.

11. Cronqvist, H.; Makhija, A.K.; Yonker, S.E. Behavioral consistency in corporate finance: CEO personal and corporate leverage. J. Financ. Econ. 2012, 103, 20-40.

12. Adams, R.B.; Ferreira, D. Women in the boardroom and their impact on governance and performance. J. Financ. Econ. 2009, 94, 291-309.

13. Ahern, K.R.; Dittmar, A.K. The changing of the boards: The impact on firm valuation of mandated female board representation. Q. J. Econ. 2012, 127, 137-197.

14. Matsa, D.A.; Miller, A.R. A female style in corporate leadership? Evidence from quotas. Am. Econ. J. Appl. Econ. 2013, 5, 136-169.

15. Tate, G.; Yang, L. Female leadership and gender equity: Evidence from plant closure. J. Financ. Econ. 2015, in press.

16. Huang, J.; Kisgen, D.J. Gender and corporate finance: Are male executives overconfident relative to female executives? J. Financ. Econ. 2013, 108, 822-839.

17. Faccio, M.; Marchica, M.T.; Mura, R. CEO gender and corporate risk-raking. Working Paper; Purdue University, West Lafayette, IN, USA, 2014.

18. Levi, M.; Li, K.; Zhang, F. Risk homeostasis and corporate acquisitions. J. Behav. Financ. Econ. 2012, 2, 21-49.

19. Levi, M.; Li, K.; Zhang, F. Director gender and mergers and acquisitions. J. Corp. Financ. 2014, $28,185-200$.

20. Bowers, H.M.; Miller, R.E. Choice of investment banker and shareholders wealth of firms involved in acquisitions. Financ. Manag. 1990, 19, 34-44.

21. Servaes, H.; Zenner, M. The role of investment banks in acquisitions. Rev. Financ. Stud. 1996, 9, 787-815.

22. Rau, P.R. Investment bank market share, contingent fee payments, and the performance of acquiring firms. J. Financ. Econ. 2000, 56, 293-324.

23. Kisgen, D.J.; Qian, J.; Song, W. Are fairness opinions fair? The case of mergers and acquisitions, J. Financ. Econ. 2009, 91, 179-207.

24. Bao, J.; Edmans, A. Do investment banks matter for M\&A returns? Rev. Financ. Stud. 2011, 24, 2286-2315.

25. Golubov, A.; Petmezas, D.; Travlos, N.G. When it pays to pay your investment banker: New evidence on the role of financial advisors in M \& As. J. Financ. 2012, 67, 271-312. 
26. Barber, B.M.; Odean, T. Boys will be boys: Gender, overconfidence, and common stock investment. Q. J. Econ. 2001, 116, 261-292.

27. Lenney, E. Women's self-confidence in achievement settings. Psychol. Bull. 1977, 84, 1-13.

28. Knight, J. Sexual stereotypes. Nature 2002, 415, 254-256.

29. Sax, L. Why Gender Matters; Doubleday: New York, NY, USA, 2005.

30. Fama, E.; French, K. Industry costs of equity. J. Financ. Econ. 1997, 43, 153-193.

31. Farrell, K.A.; Hersch, P.L. Additions to corporate boards: The effect of gender. J. Corp. Financ. 2005, 11, 85-106.

32. Paul, D.L. Board composition and corrective action: Evidence from corporate responses to bad acquisition bids. J. Financ. Quant. Anal. 2007, 42, 759-784.

33. Byrd, J.W.; Hickman K.A. Do outside directors monitor managers? J. Financ. Econ. 1992, 32, $195-221$.

34. Shivdasani, A. Board composition, ownership structure, and hostile takeovers, J. Account. Econ. 1993, 16, 167-198.

35. Cotter, J.F.; Shivdasani, A.; Zenner, M. Do independent directors enhance target shareholder wealth during tender offers? J. Financ. Econ. 1997, 43, 195-218.

36. Hermalin, B.E.; Weisbach, M.S. Endogenously chosen boards of directors and their monitoring of the CEO. Am. Econ. Rev. 1998, 88, 96-118.

37. Derrien, F.; Dessaint, O. The effects of investment bank rankings: Evidence from M \& A league tables. Working Paper; HEC Paris, France, and University of Toronto, Canada, 2014.

(C) 2015 by the authors; licensee MDPI, Basel, Switzerland. This article is an open access article distributed under the terms and conditions of the Creative Commons Attribution license (http://creativecommons.org/licenses/by/4.0/). 